\title{
Evaluation of compacted laterite soil admixed with cement and hair fibers as road construction material
}

\author{
Oluremi J. R.*, Adedokun S. I.**, Yohanna P.***, Fadiran D. A.* and Azeez I. O.* \\ *Department of Civil Engineering, Ladoke Akintola University of Technology, Ogbomoso, Oyo State, Nigeria \\ **Department of Civil Engineering, University of Lagos, Lagos State, Nigeria \\ ***Department of Civil Engineering, University of Jos, Plateau State, Nigeria \\ *Corresponding Author: jroluremi@lautech.edu.ng
}

\begin{abstract}
Natural laterite soil, classified as A-5 (4) based on American Association of State Highway and Transportation Officials (AASHTO) soil classification system and ML-CL according to Unified Soil Classification System (USCS), was admixed with ordinary Portland cement and synthetic hair fibers (SHF) were evaluated as road construction material. Soil specimens were made by mixing lateritic soil with up to $4 \%$ cement in $1 \%$ step concentration and up to $12 \%$ SHF in $2 \%$ step concentration of by dry weight of the soil and subjected to British Standard Light (BSL) or Standard Proctor method of compaction, unconfined compressive strength (UCS), and California bearing ratio (CBR) tests. Results indicated a decrease in the values of optimum moisture content (OMC), while no general trend was established for maximum dry density (MDD). The values of UCS and CBR increased as the content of both cement and SHF increased. Analysis of variance (ANOVA) of the results shows some level of significance on some geotechnical properties considered. Regression analysis on the results shows that MDD, OMC, cement, and SHF significantly influenced the UCS and CBR values of the stabilized soil with correlation coefficient values $\left(\mathrm{R}^{2}\right)$ of 82.9 and $83.3 \%$, respectively. Based on the results, an optimal blend of 3\% cement $9 \%$ SHF significantly improved the soil properties and is recommended for improving the geotechnical properties of lateritic soil treated with cement/ synthetic hair fiber as road construction material.
\end{abstract}

Keywords: Lateritic soil; Cement; Synthetic hair fibre; Regression analysis; Analysis of variance.

\section{INTRODUCTION}

Industrialization, population increase, and economic development, though a pivot to the world development, have been sources of increasing waste generation with indiscriminate disposal all over the globe. Proper disposal of agricultural, industrial, and human generated waste is one of the major menaces facing the world to which urgent attention and cost effective solutions should be proffered, due to consequential debilitating and hazardous effects on the environment and human health. Acute environmental problems relating to treatment and disposal of waste are usual occurrence caused by continuous generation of industrial by-product and agricultural residual wastes (Oriola and Moses, 2010); this made recent researches (Deepjyoti et al., 2016; Ochepo, 2014; Oluremi et al., 2012; 2013; 2016a, 2016b; Osinubi et al., 2015; Wajid et al., 2016; Adedokun et al., 2018; Oluremi et al., 2018) focus on utilization of various wastes which include hair fibers for both engineering purposes and economic sustainability.

Synthetic hair fibers (SHF) obtained from female saloon as a residue during hair dressing by hair stylists are considered valueless solid wastes. Generally, the length of these synthetic hair fibers may vary from 5 to $120 \mathrm{~mm}$, while the aspect ratio may vary from 290 to 500. Residual human hair fiber (HHF), on the other hand, is a natural non-biodegradable waste material with length ranging from $5 \mathrm{~mm}$ to $50 \mathrm{~mm}$ and aspect ratio ranging from 290 to 500 (Wajid et al., 2014). Both synthetic and human hair fibers, if not properly disposed, will constitute health and environmental hazards because of their non-biodegradable nature (Wajid et al., 2016).

Laterite soil have been described as highly weathered residual soil formed by disintegration and decomposition of rocks under the forces of physical, chemical, and biological weathering processes and some prevailing environmental 
conditions (Blight, 1997; Abebaw, 2005). During the process, parent rock and rock minerals break down and release their internal energy to form a more stable material called soils with a lower internal energy. Physical and biological processes increase the surface area of the rock to enhance the weathering effect of chemical processes. Although relative to seasonal changes, environmental and climatic conditions and topography influence the rate of weathering. Engineering properties of laterites are mostly influenced by the parent rock material, environmental, climatic conditions, and the prevailing weathering process. This normally initiates heterogeneity into the properties of the laterite soil and render the soil unsuitable as material for highway foundation. These types of soil are termed marginal soil of low workability, which are easily affected by the increase in moisture content and hence the need for their stabilization.

Although several literatures exist on lateritic soils treated with hair fibers, limited researches exist on Nigerian lateritic soils treated with cement-hair fiber blend as road construction material. This study was therefore aimed at investigating the effect of residual synthetic hair fiber, which is considered a waste material as admixture in the compacted laterite soil stabilized with cement as a road construction material with the objectives of improving the geotechnical properties of the soil under varying stepped concentration of cement and hair fibers and to provide innovative means of disposing residual synthetic hair fibers in an environmental friendly way as well.

\section{LITERATURE REVIEW}

Application of randomly placed natural and synthetic fibers for the reinforcement of soils has been practised in the past in geotechnical engineering (Estabragh et al., 2011). Recent researches around the world (Inod et al., 2007; Ramesh et al., 2010; Sanjay and Bhawana 2012; Manjunath et al., 2013; Treasa and Sudheesh, 2013; Ahmad, 2014; Rohin, 2014; Tomas, 2014; Wajid et al., 2014; Deepjyoti et al., 2016; Wajid et al., 2016) focused on the use of short, discrete and randomly oriented fibers for engineering applications.

Kalpana and Solanki (2009) mixed polyester fibers with clayey soil in various proportions ( $0 \%$ up to $1.50 \%$ by weight of dry clayey soil at an interval of $0.25 \%$ ) and the samples were examined for basic geotechnical parameters, which include unconfined compression, shear strength parameters, consolidation, and CBR. Results showed that there was increase in the strength properties of clayey soil up to the $0.50 \%$ inclusion of fibers.

Wajid et al. (2014) worked on the mixture of lateritic soil and randomly placed human hair fibre, with an aspect ratio ranged from 295 to 500 and of different length and equivalent diameter. California bearing ratio (CBR) test was performed on the samples to ascertain their strength property with the purpose of improving the soil and determining the optimum fibre content and length. The results, relative to the strength of non-reinforced soil, show that the inclusion of HHF improved the strength significantly from 13 to $16 \%$ and also prevented the samples from cracking.

Experimental study of Abhijith (2015) on the effect of natural coir fibers on CBR of subgrade soil showed that natural coir fiber increases the strength of subgrade soil and improves the pavement life as well. Similarly, the effect of scrap rubber tyre as synthetic fibers on the strength and dynamic properties of clayey soils was investigated by Akbulut et al. (2007). They subject both the reinforced and the unreinforced samples to shear box, unconfined compression, and resonant frequency tests. It was discovered that waste rubber fibers improved the strength properties and dynamic behaviour of clayey soils. Effectiveness of sisal fibers for improving the strength of lime stabilized bentonite admixed with Phosphogypsum (PG) using unconfined compressive strength (UCS) test was investigated by Kumar and Dutta (2014). The results showed that $8 \%$ lime admixed with $8 \%$ PG and reinforced with $1 \%$ sisal fibers initiates the highest UCS value.

Cement stabilization of lateritic soil is not a new technique of soil improvement in geotechnical engineering. Researchers (Uddin, et al., 1997; Lo and Wardani, 2002; Basha, et al., 2005; Bagheri, et al., 2014; Roy, 2014) have worked and reported extensively on cement stabilization of soil. According to the reports of PCA (1995) and CEER (2013) the normal range of cement content by percentage of soil weight for stabilizing A-1-a soils is 3-5\%, while for A-6 soils it is $9-15 \%$. This implies that the poorer the soil based on the classification of the soil, the higher the cement content required for its stabilization, which can therefore cumulatively affect adverse cost implications on the stabilization process and hence the need to improve the stabilization with another cost effective and readily available material as auxiliary additive. 


\section{MATERIALS AND METHODS}

\section{Materials}

Soil: Soil material was collected from a borrowed pit along Ogbomosho-Ilorin Express Road. The soil was air-dried, pulverized, and sieved through British Standards (BS) No. 4 sieve $(4.75 \mathrm{~mm}$ aperture) as required for laboratory tests (Head, 1992).

Synthetic Hair Fibers: The synthetic hair fibers used were sourced as a residue from a female's hair dressing saloon in Ogbomoso metropolis, Nigeria. These fibers are considered as valueless solid wastes, which create environmental problems because of their non-biodegradability in nature. The length of the fibers varies from 5 to $120 \mathrm{~mm}$ generally with aspect ratio ranging from 290 to 500 . The synthetic hair was cut into an average length of $10 \mathrm{~mm}$. A typical picture of synthetic hair fibers after cutting is shown in figure 1.

Cement: The cement used for the study was ordinary Portland cement sourced from an open market in Ogbomoso, Oyo state, Nigeria.

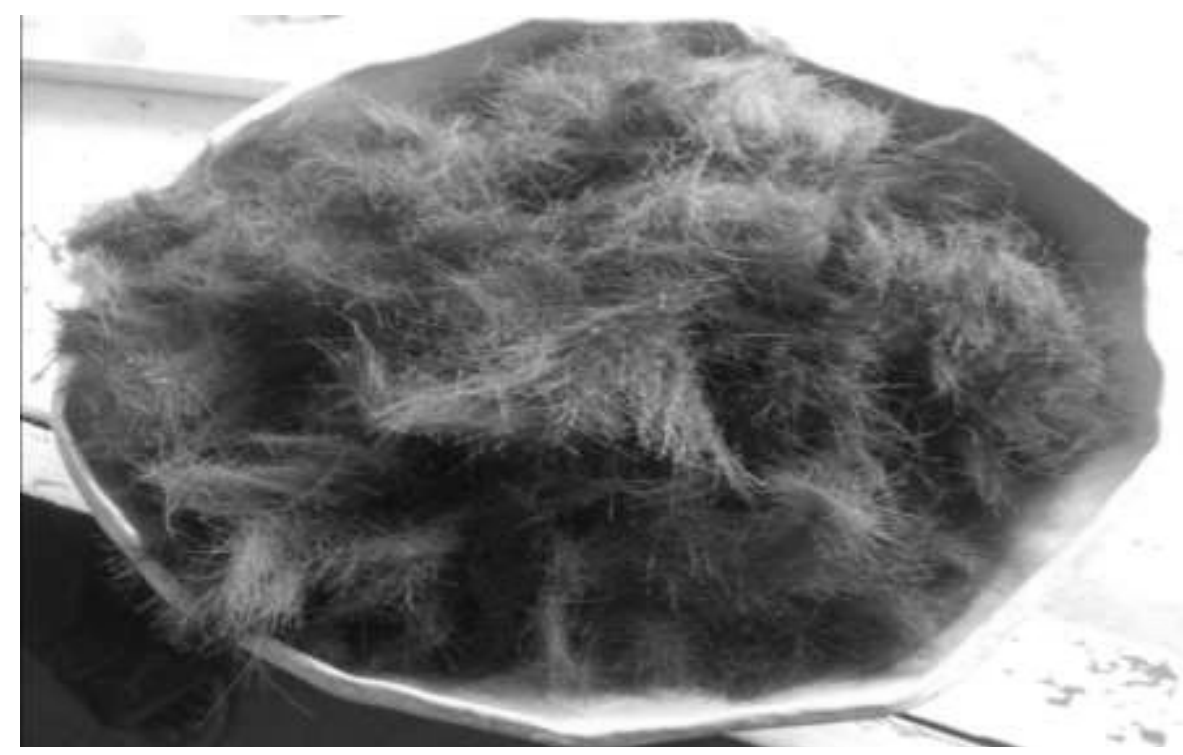

Figure 1. Synthetic Hair Fiber obtained from a female's hair dressing saloon in Ogbomoso metropolis, Nigeria, after being chopped.

\section{Methods}

Index Properties: Index properties of both natural laterite soil and laterite soil - cement - hair fiber mixtures were determined using laboratory tests according to British Standards BS 1377 (1990) and BS 1924 (1990), respectively.

Compaction: Compaction is a measure of the soil density-moisture relationship aimed at determining the moisture content at which the dry density of the compacted soil is maximum. Test was carried out using the proctor mould, which involves exerting twenty seven (27) blows of $2.5 \mathrm{~kg}$ rammer falling from $300 \mathrm{~mm}$ on each of three layers of soil placed in a British Standard mould, according to BS 1377 (1990) and BS 1924(1990). Specimens were prepared in stepped concentrations of $1,2,3$, and $4 \%$ cement and $0,3,6$, and $12 \%$ Hair fiber content, respectively, by dry weight of soil.

Unconfined compressive strength: The unconfined strength test is a measure of the soil shear strength basically used to assess the bearing capacity of the soil. The unconfined compression test was carried out on the compacted soil specimens according to BS 1377: (1990) Part 7 test 2, while outlined procedure in BS 1924 (1990) was used for 
the cement stabilized soil samples admixed with synthetic hair fiber. Soil samples were compacted using the proctor energy at their respective OMCs. With the use cylindrical cone of internal diameter of $23.5 \mathrm{~mm}$ by $48 \mathrm{~mm}$ height and a jack, samples were cored, extruded, and trimmed to size $23.5 \mathrm{~mm}$ diameter by $47 \mathrm{~mm}$ height. The cored samples were cured for seven and fourteen days, respectively, and then crushed between the frames of the UCS machine as shown in Figure 2. The stress at failure is taken as the UCS value of the specimen.

Durability: Durability is defined as the ability of the compacted soil or soil-admixture composite to maintain its integrity under adverse field condition. The worst prevailing field environmental conditions was simulated on the sample. This was done by completely immersing compacted cement-laterite soil-SHF mixture, waxed cured specimens in water to determine the resistance to loss in strength. This procedure is more acceptable because Nigeria is part of tropical regions where wetting and drying are the prevailing environmental conditions (Ola, 1974). The resistance to loss in strength is defined as the ratio of the unconfined compressive strength of 7 days wax-cured specimens, which are then de-waxed top and bottom and immersed in water for another 7 days to allow for water absorption, to unconfined compressive strength of 14 days wax-cured specimens. The resistance to loss in strength is computed using Equation 1, as recommended by Ola (1974).

Resistances to Loss in Strength $=\frac{\text { USC }(7 \text { Days cured }+7 \text { Days soaked })}{\text { UCS(14 Days cured })}$

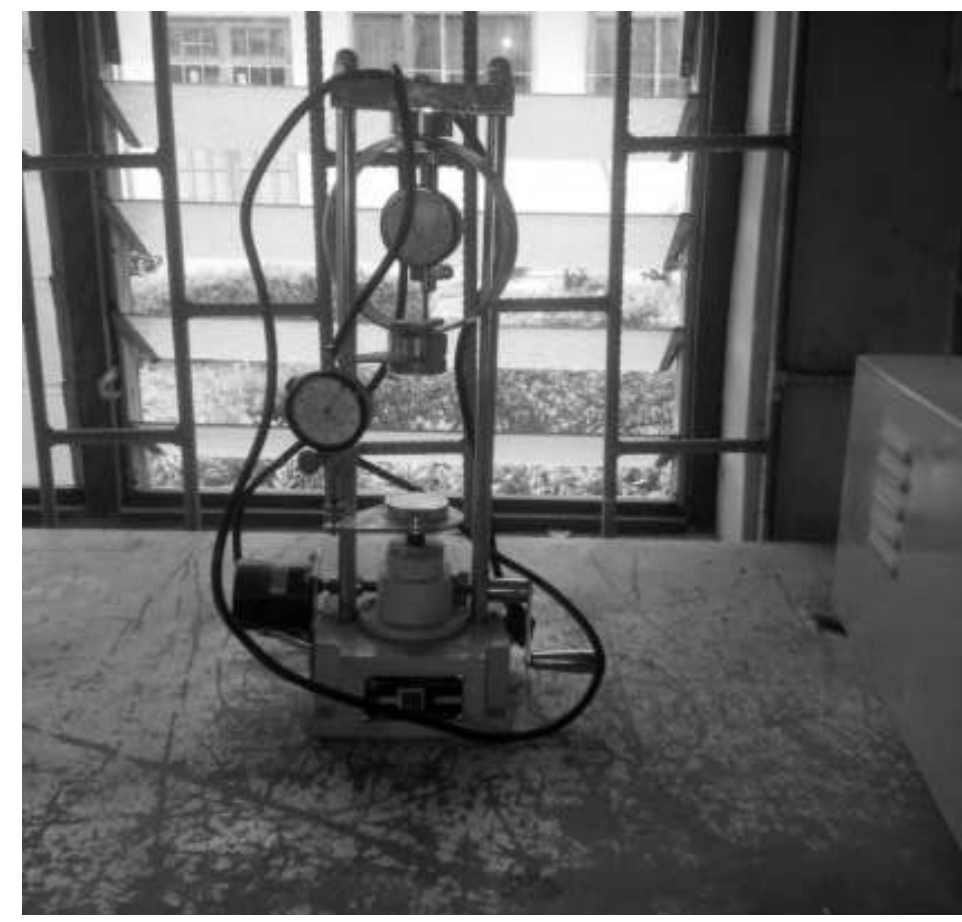

Figure 2. Crushing of samples in unconfined compression machine.

\section{California Bearing Ratio (CBR)}

The California bearing ratio is an empirical test first developed in California, United States of America, to simply determine the bearing values of flexible pavement materials (sub-base and subgrades) as described by Head (1992). The test was conducted in accordance with BS 1377 (1990) and BS 1924 (1990) for the natural and treated soils. $5 \mathrm{~kg}$ of dry natural laterite soil and cement-synthetic hair fiber-laterite soils were mixed thoroughly with water at OMCs derived from the respective compaction tests. The mix was compacted in three layers by exerting 62 blows of British Standard light rammer (2.5kg rammer) on each layer inside CBR moulds. The top surface was scraped and 
levelled with the scraper after compaction of the third layer, and the compacted sample was cured for six days (inside cellophane bag) before testing. The loading was then applied at strain rate of $1.25 \mathrm{~mm} / \mathrm{min}$. Loading was recorded at the following penetrations for both the top and bottom (base) layers from 0.5 to $7 \mathrm{~mm}$ by increasing 0.5 intervals. For the soaked condition, the same process was carried out again but samples were soaked by full immersion in water for $24 \mathrm{hrs}$ minimum before applying the penetration load from CBR machine.

The CBR values were calculated using Equations 2 and 3 as specified by BS 1377(1990) and BS 1924 (1990).

$C B R$ at $2.5 \mathrm{~mm}$ penetration $=\frac{\text { actual load in } \frac{\mathrm{kg}}{\mathrm{cm}} \text { exerted on soil }}{\text { standard laod at } 2.5 \mathrm{~mm} \text { penetration in } \frac{\mathrm{kg}}{\mathrm{cm}}}$

CBR at $5.0 \mathrm{~mm}$ penetration $=\frac{\text { actual load in } \frac{\mathrm{kg}}{\mathrm{cm}} \text { exerted on soil }}{\text { standard laod at } 5.0 \mathrm{~mm} \text { penetration } \operatorname{in} \frac{\mathrm{kg}}{\mathrm{cm}}}$

\section{RESULTS AND DISCUSSION \\ Index properties}

The liquid limit, plastic limit, and plasticity index of the natural laterite soil are $47.6 \%, 41.15 \%$, and $6.53 \%$, respectively. The particle size distribution curve for natural soil is shown in figure 3, and the percentage passing BS sieve No. 200 is 55.4\%; thus, the effective size of the soil is of micro-size, which makes the soil unsuitable for road construction. With these results, the soil was classified as A-5(4) soil based on AASHTO Classification System (AASHTO, 1986) and ML-CL soil based on Unified Soil Classification System (USCS) (ASTM, 1992). The properties of the natural laterite soil are summarily highlighted in Table 1.

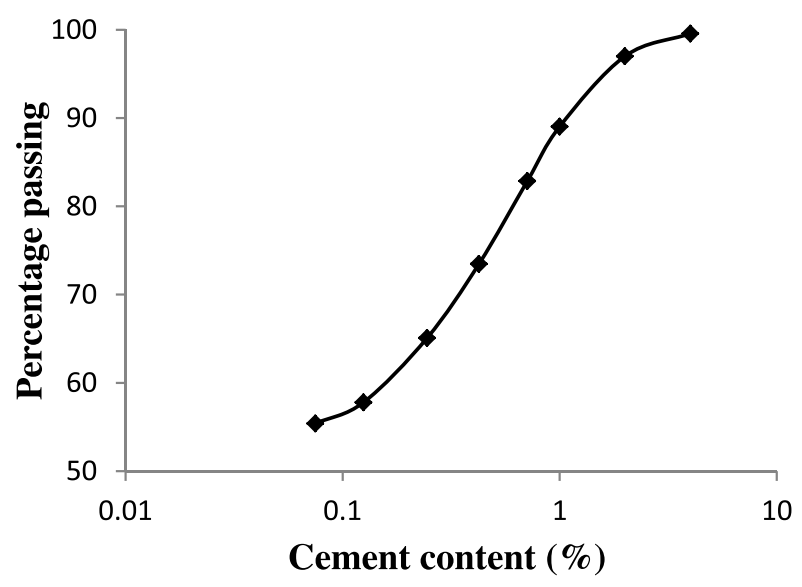

Figure 3. Particle size distribution for the natural laterite soil.

\section{Effect of Cement-Hair Fiber Content on Compacted Cement Stabilized Laterite Soil Compaction Characteristics}

\section{Maximum dry density}

The variation of maximum dry density of cement-synthetic hair fiber-laterite soil is shown in Figure 4 . There was no precise trend established for maximum dry density as the contents of both cement and SHF increased, and hence the effect of SHF on the compaction characteristics of the stabilized laterite soil is not conclusively determined. 
Table 1. Properties of natural laterite soil.

\begin{tabular}{|l|c|}
\hline Properties (Test) & Result \\
\hline Natural Moisture Content (\%) & 15.4 \\
\hline Percentage passing sieve 75 $\mu \mathrm{m}($ No. 200$)$ & 55.4 \\
\hline Specific gravity & 1.91 \\
\hline Liquid Limit (\%) & 47.6 \\
\hline Plastic limit (\%) & 41.07 \\
\hline Plasticity Index (\%) & 6.53 \\
\hline AASHTO Classification & A-5(4) \\
\hline USCS Classification & ML-CL \\
\hline OMC at BSL Compaction (\%) & 18.5 \\
\hline MDD at BSL compaction (g/cm $\left.{ }^{3}\right)$ & 1.74 \\
\hline UCS at BSL Compaction (14days Cured) & 214.83 \\
UCS at BSL Compaction (7days cured and 7days soaked) & 145.81 \\
\hline
\end{tabular}

A two - way analysis of variance (ANOVA) statistical test on the collated values of maximum dry density shows that both cement $\left(\mathrm{F}_{\mathrm{CAL}}=0.049476<\mathrm{F}_{\mathrm{CRIT}}=3.490295\right)$ and synthetic hair fiber $\left(\mathrm{F}_{\mathrm{CAL}}=0.996563<\mathrm{F}_{\mathrm{CRIT}}=3.259167\right)$ had no statistically significant effects on laterite soil - cement - SHF compacted mixtures. Therefore, none of these two additives could be used in adjudging or predicting the behaviour of the maximum dry density of the stabilized soil. Detailed results are shown in Table 2.

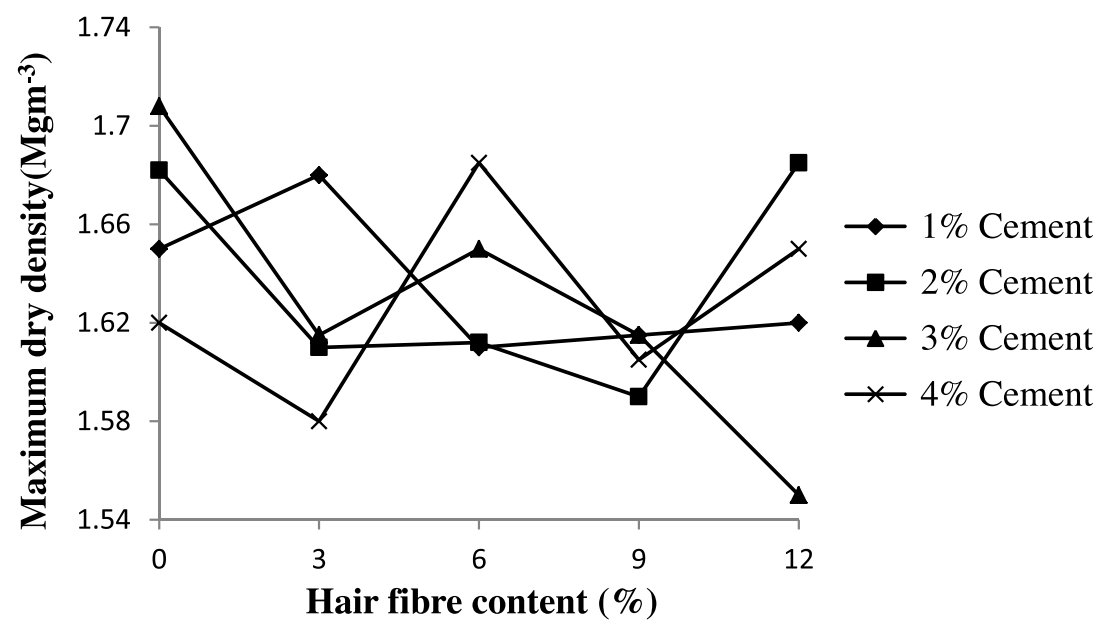

Figure 4. Variation of maximum dry density of compacted laterite soil-cement-synthetic hair fiber mixture. 
Table 2. Analysis of Variance (Two-way) for Compaction Characteristics of Compacted Laterite Soil-Cement-Synthetic Hair fiber mixtures.

\begin{tabular}{|c|c|c|c|c|c|c|c|}
\hline \multicolumn{2}{|c|}{ Property } & $\begin{array}{c}\text { Source of } \\
\text { Variation }\end{array}$ & $\begin{array}{c}\text { Degree of } \\
\text { Freedom }\end{array}$ & F $_{\text {CAL }}$ & P-value & F $_{\text {CRIT }}$ & Remark \\
\hline \multirow{3}{*}{$\begin{array}{c}\text { Compaction } \\
\text { characteristics }\end{array}$} & \multirow{2}{*}{ MDD } & Cement & 3 & 0.049476 & 0.984728 & 3.490295 & NS \\
\cline { 2 - 8 } & \multirow{2}{*}{ OMC } & Hair fibre & 4 & 0.996563 & 0.446555 & 3.259167 & NS \\
\cline { 2 - 8 } & Cement & 3 & 6.793112 & 0.006273 & 3.490295 & SS \\
\cline { 2 - 8 } & Hair fibre & 4 & 2.317487 & 0.116571 & 3.259167 & NS \\
\hline
\end{tabular}

$\mathrm{NS}=$ No Significant Effect; $\mathrm{SS}=$ Significant Effect; $\mathrm{F}_{\mathrm{CAL}}=$ Calculated factor,

$\mathrm{F}_{\mathrm{CRIT}}=$ Critical factor, $\mathrm{P}$-value $=$ Level of significance

\section{Optimum moisture content}

The changes in the optimum moisture content (OMC) with SHF content for cement stabilized laterite soil are shown in figure 5. There was initial increase in the optimum moisture content with increase in the SHF content from 0 up to $3 \%$ SHF after which it decreased progressively up to $12 \%$ SHF content. The reduction in the OMC may be connected with the reduction in the water holding capacity of the soil as the percentage SHF content increased. These results agree with the findings of Osinubi et al. (2015).

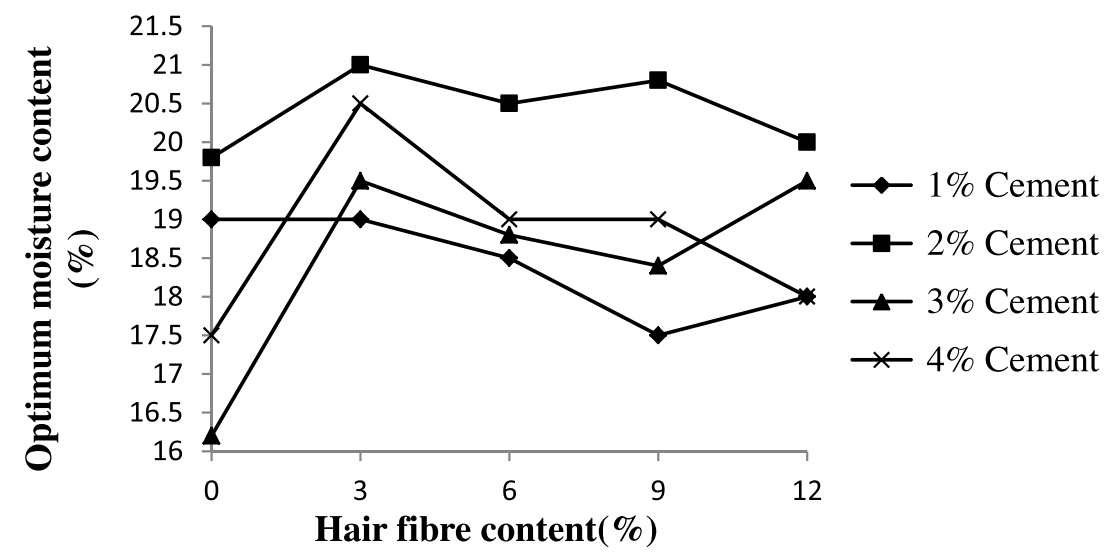

Figure 5. Variation of optimum moisture content of compacted laterite soil-cement-synthetic hair fiber mixture.

Two-way analysis of variance (ANOVA) on the collated values of OMC from compaction test shows that effects of cement $\left(\mathrm{F}_{\mathrm{CAL}}=6.793112>\mathrm{F}_{\mathrm{CRIT}}=3.4902952\right)$ were statistically significant on cement stabilized laterite soil admixed with SHF, while SHF $\left(\mathrm{F}_{\mathrm{CAL}}=2.317487<\mathrm{F}_{\mathrm{CRIT}}=3.259167\right)$ had no statistically significant effects on cement stabilized laterite soil admixed with SHF. As a result, in this case, cement only could be used in predicting the OMC of compacted cement stabilized laterite soil-SHF mixture. The detailed results are shown in Table 2.

\section{Unconfined Compressive Strength Test (UCS)}

14 days curing: The variation of unconfined compressive strength of 14 days cured compacted laterite soil-cementSHF mixture specimens is shown in figure 6. From the results, UCS values increased from 143.27, 696.62, 1766.67, and $1463.23 \mathrm{kN} / \mathrm{m}^{2}$ at $1 \% \mathrm{C} / 0 \% \mathrm{HF}, 2 \% \mathrm{C} / 0 \% \mathrm{HF}, 3 \% \mathrm{C} / 0 \% \mathrm{HF}$, and $4 \% \mathrm{C} / 9 \% \mathrm{HF} \%$, respectively, to highest values of $462.21,1011.5,2015.17$, and $2098.8 \mathrm{kN} / \mathrm{m}^{2}$ at $1 \% \mathrm{C} / 9 \% \mathrm{HF}, 2 \% \mathrm{C} / 9 \% \mathrm{HF}, 3 \% \mathrm{C} / 9 \% \mathrm{HF}$, and $4 \% \mathrm{C} / 9 \% \mathrm{HF} \%$, 
respectively. A similar trend of increase in the strength properties was observed by Inod et al. (2007), Ramesh et al. (2010), Treasa and Sudheesh (2013), Deepjyoti et al. (2016), and Wajid et al. (2016) for fiber treated soil. This is attributed to the availability of sufficient water that enhances hydration reaction of cement to liberate lime, which reacts with silica and alumina in the laterite soil to produce secondary cementation compounds (Osinubi and Medubi, 1997).

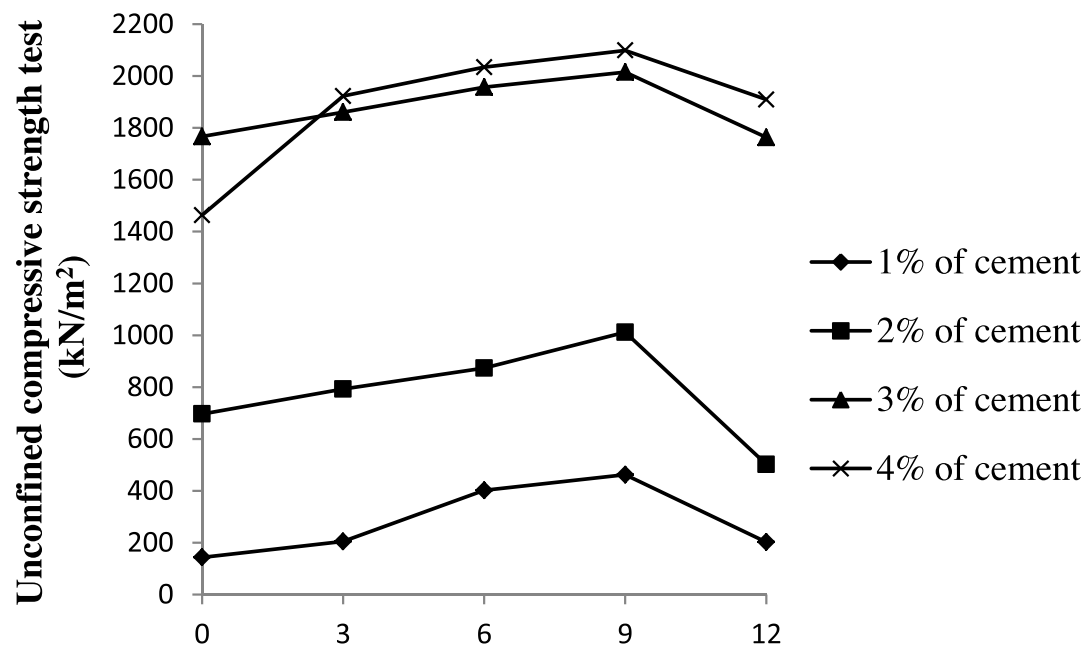

Hair fiber content $(\%)$

Figure 6. Variation of UCS of 14 days cured compacted laterite soil-cement-synthetic hair fiber mixture.

According to Deepjyoti et al. (2016) in shear strength enhancement of sandy soil using hair fiber, the soil that shows brittle failure usually has lower strength, but the use of fibers provides ductility to the soil and hence increasing strength, which might result from increase in friction developed between the soil and the reinforcing material. This serves as a mechanism for transferring load that is built up in the soil mass to the reinforcement material (Deepjyoti et al., 2016).

A two-way analysis of variance (ANOVA) on the results of unconfined compressive strength for samples cured for 14 days, the detailed results of which are in Table 3, shows that both cement $\left(\mathrm{F}_{\mathrm{CAL}}=285.371>\mathrm{F}_{\mathrm{CRIT}}=3.490\right)$ and SHF $\left(\mathrm{F}_{\mathrm{CAL}}=8.532>\mathrm{F}_{\mathrm{CRIT}}=3.259\right)$ had statistically significant effects on cement stabilized laterite soil admixed with synthetic hair fiber; however, cement has a more pronounced effect. Therefore, both cement and SHF contents could be used effectively in predicting the unconfined compressive strength of the cement stabilized laterite soil admixed with SHF.

7 days curing +7 days soaking: The variations of UCS values (7 days curing, 7 days soaking) of compacted soilcement-SHF mixtures are shown in figure 7. Generally, the UCS values increased with both cement and SHF content. It is pertinent to note here that the UCS values for the soaked specimens are far too low, which could be due to the ingress of water that resulted in loss of strengths. Similar observation of increase in the strength properties was noted in hair fiber treated soil by Inod et al. (2007), Ramesh et al. (2010), Treasa and Sudheesh (2013), Deepjyoti et al. (2016), and Wajid et al. (2016).

Two-way analysis of variance (ANOVA) on the collated values of unconfined compressive strength for samples cured 7 days and soaked for 7 days shows that the effect of both cement $\left(\mathrm{F}_{\mathrm{CAL}}=264.733>\mathrm{F}_{\mathrm{CRIT}}=3.490\right)$ and $\mathrm{SHF}\left(\mathrm{F}_{\mathrm{CAL}}=\right.$ 9.2096 $>\mathrm{F}_{\mathrm{CRIT}}=3.259$ ) was statistically significant on laterite soil-cement-SHF mixtures with cement having a more pronounced effect. Detailed results are shown in Table 3. 
Table 3. Analysis of Variance (Two-way) for Strength Characteristics of Compacted Laterite Soil-Cement-Hair Fiber Mixtures.

\begin{tabular}{|c|c|c|c|c|c|c|c|}
\hline \multicolumn{2}{|c|}{ Property } & $\begin{array}{l}\text { Source of } \\
\text { Variation }\end{array}$ & $\begin{array}{l}\text { Degree of } \\
\text { Freedom }\end{array}$ & $\mathbf{F}_{\mathrm{CAL}}$ & P-value & $\mathbf{F}_{\text {CRIT }}$ & Remark \\
\hline \multirow{4}{*}{$\begin{array}{l}\text { Unconfined } \\
\text { compressive } \\
\text { strength }\end{array}$} & \multirow{2}{*}{ UCS 14 days } & Cement & 3 & 285.371 & $2.03 \mathrm{E}-11$ & 3.490 & SS \\
\hline & & Hair fibre & 4 & 8.532 & 0.001686 & 3.259 & SS \\
\hline & \multirow{2}{*}{$\begin{array}{l}\text { 7days cured }+7 \\
\text { days soaked }\end{array}$} & Cement & 3 & 264.733 & $3.17 \mathrm{E}-11$ & 3.490 & SS \\
\hline & & Hair fibre & 4 & 9.2096 & 0.001 & 3.259 & SS \\
\hline \multirow{2}{*}{ Durability } & \multirow{2}{*}{$\begin{array}{l}\text { Resistance to loss } \\
\text { in strength }\end{array}$} & Cement & 3 & 1.692 & 0.221 & 3.490 & NS \\
\hline & & Hair fibre & 4 & 0.389 & 0.812 & 3.259 & NS \\
\hline \multirow{4}{*}{$\begin{array}{c}\text { California } \\
\text { bearing ratio }\end{array}$} & \multirow{2}{*}{ Unsoaked CBR } & Cement & 3 & 51.489 & 3.99E-07 & 3.490 & SS \\
\hline & & Hair fibre & 4 & 10.070 & 0.000822 & 3.259 & SS \\
\hline & \multirow{2}{*}{ Soaked CBR } & Cement & 3 & 0.457 & 0.71762 & 3.490 & NS \\
\hline & & Hair fibre & 4 & 1.713 & 0.211641 & 3.259 & NS \\
\hline
\end{tabular}

$\mathrm{NS}=$ No Significant Effect; $\mathrm{SS}=$ Significant Effect; $\mathrm{F}_{\mathrm{CAL}}=$ Calculated factor, $\mathrm{F}_{\mathrm{CRIT}}=$ Critical factor, $\mathrm{P}$-value $=$ Level of significance

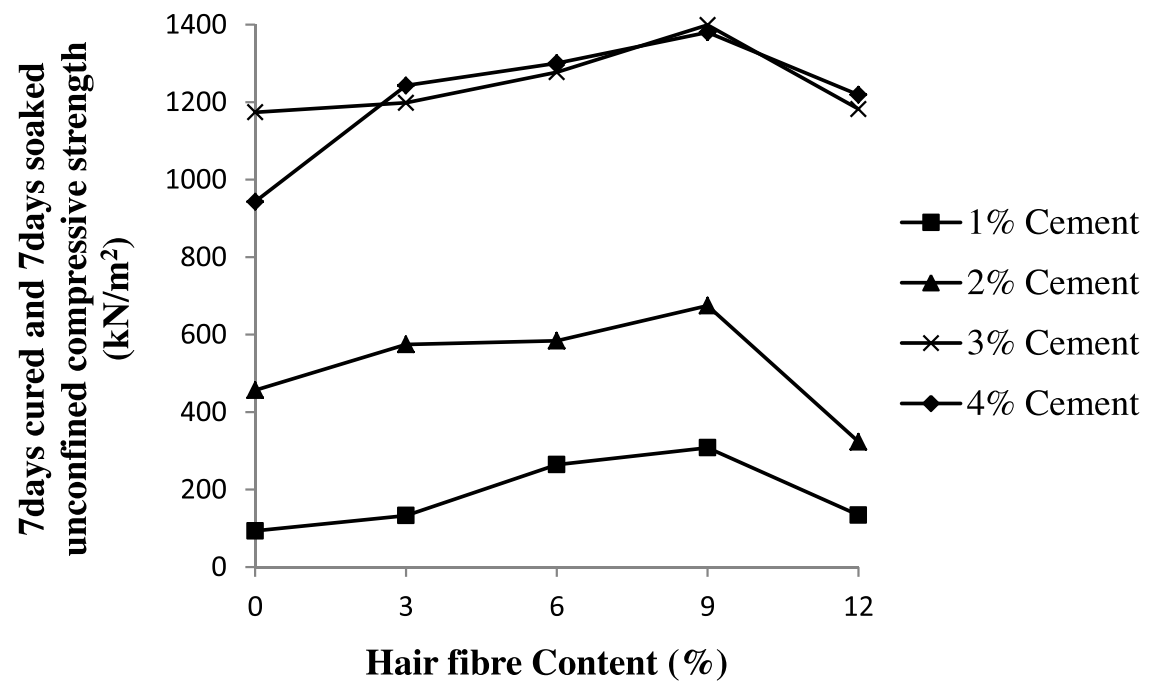

Figure 7. Variation of UCS of 7-day cured-7-day soaked compacted laterite soil-cement-synthetic hair fiber mixture.

\section{Durability Assessment}

Generally, no consistent trend was established for both durability parameters, i.e., loss in strength and resistance to loss in strength, with increase in both cement and SHF contents as revealed in Figures 8 and 9, respectively. However, as the cement content increased, there was increase in the loss in strength (Figure 8 ) except at $2 \%$ cement content. This might be due to the formation of composite material, resulting from the reaction of cement and laterite soil.

Two-way analysis of variance (ANOVA) statistical test on the results of durability assessment shows that both cement $\left(\mathrm{F}_{\mathrm{CAL}}=1.692<\mathrm{F}_{\mathrm{CRIT}}=3.490\right)$ and hair fiber $\left(\mathrm{F}_{\mathrm{CAL}}=0.389<\mathrm{F}_{\mathrm{CRIT}}=3.259\right)$ had no statistically significant effects on 
laterite soil-cement-hair fiber mixtures. This reveals the dominant detrimental effect of water on the durability of the stabilized lateritic soil generally, which must be carefully prevented. Detailed results are shown in Table 3.

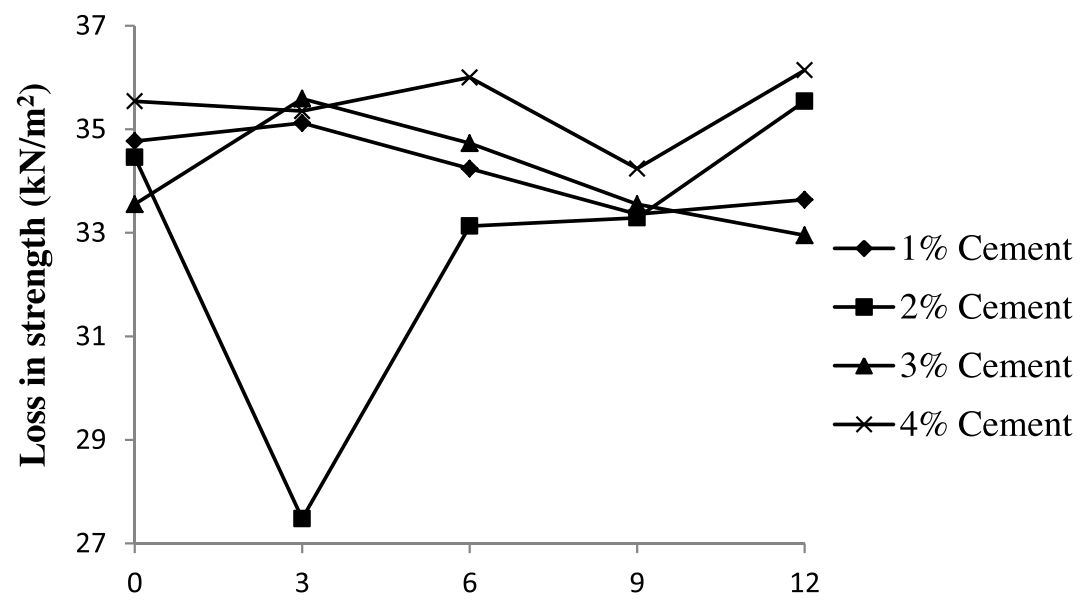

Hair fibre Content (\%)

Figure 8. Variation of loss in strength of compacted laterite soil-cement-synthetic hair fiber mixtures.

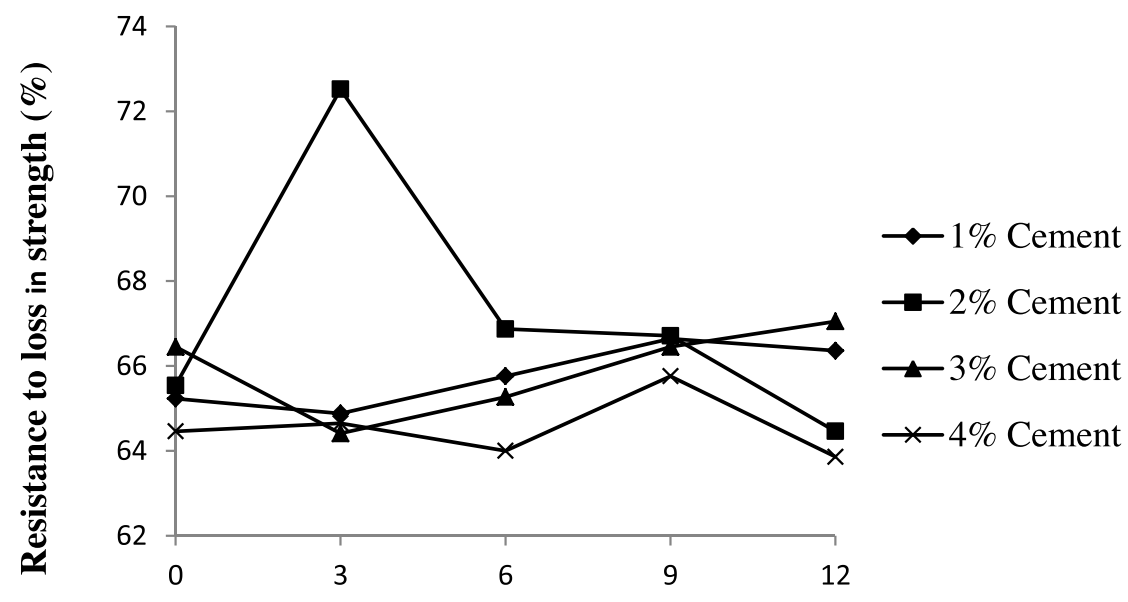

Hair fibre Content $(\%)$

Figure 9. Variation of resistance to loss in strength of compacted laterite soil-cement-synthetic hair fiber mixtures.

\section{California bearing ratio}

The variation of the CBR of cement stabilized laterite soil with synthetic hair fiber (SHF) content for the unsoaked samples is shown Figure 10. It can be generally stated that the CBR values increased as SHF content increased up to $9 \%$ SHF and later reduced at $12 \%$ SHF content for all percentage of cement used in stabilizing the samples. Also, the CBR of the samples increased with increasing cement content; this is to be expected as the cement enhanced the aggregation as well as the cohesion of the soil particles, which promote strong bonding and hence strength of the samples.

However, in Figure 11, which represents the variation of CBR values of cement stabilized laterite soil with increase in SHF content for the soaked samples, a significant reduction in the CBR values was observed due to the effects of the 
soaking process, which completely overcame the strength enhancing capacity of cement in stabilization. The might be due to the presence of much interconnected voids, which facilitated easy percolation of water through the samples, which is detrimental to strength development.

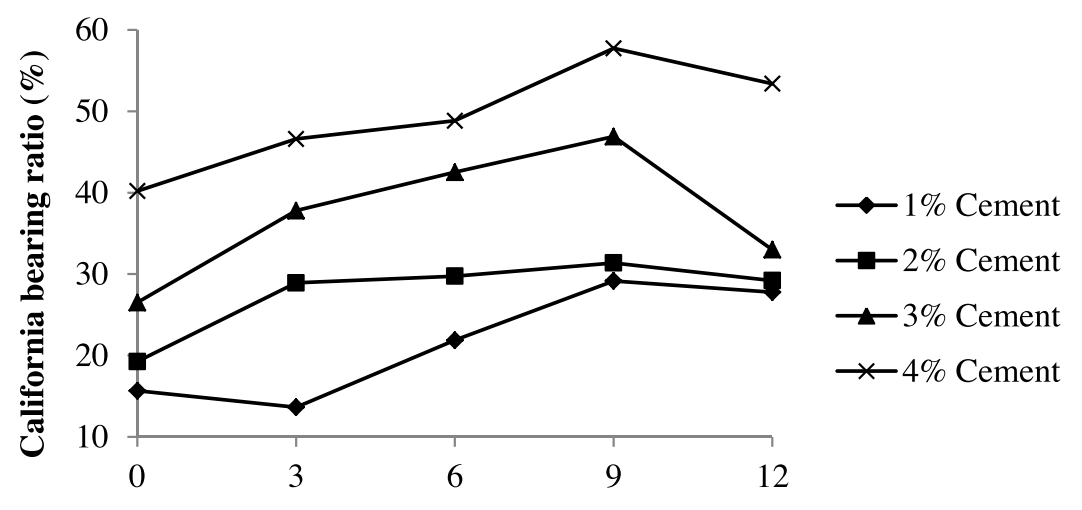

Hair fibre content $(\%)$

Figure 10. Variation in California bearing ratio of unsoaked compacted laterite soil-cement-synthetic hair fiber mixtures.

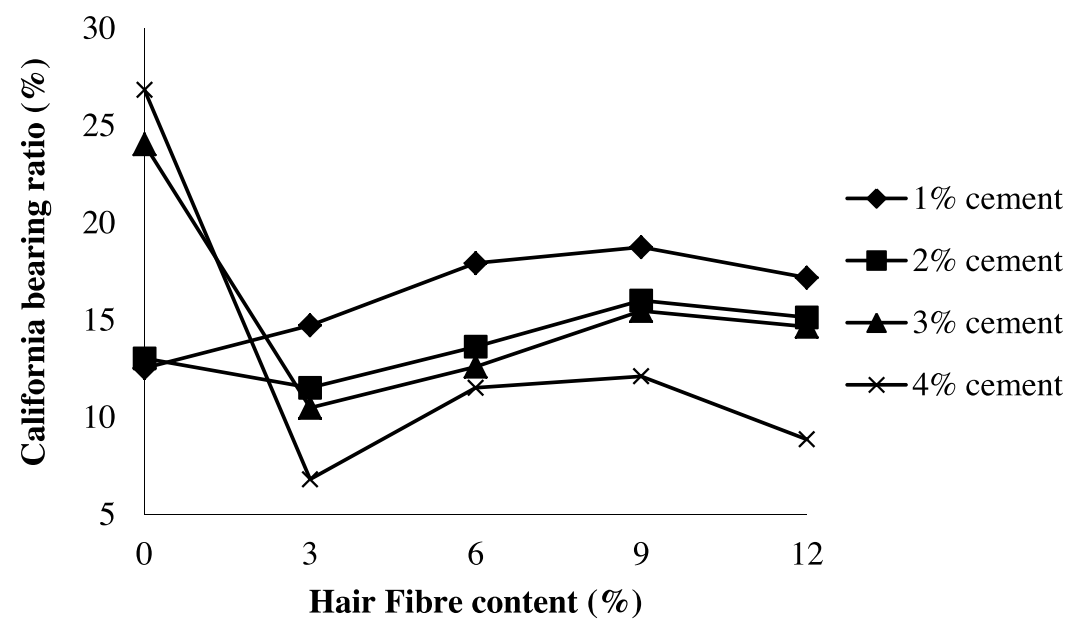

Figure 11. Variation in California bearing ratio of 48-hour soaked compacted laterite soil-cement-synthetic hair fiber mixtures.

Two-way analysis of variance (ANOVA) statistical test on the results of unsoaked CBR test shows that the effects of both cement $\left(\mathrm{F}_{\mathrm{CAL}}=51.489>\mathrm{F}_{\mathrm{CRIT}}=3.490\right)$ and $\mathrm{SHF}\left(\mathrm{F}_{\mathrm{CAL}}=10.070>\mathrm{F}_{\mathrm{CRIT}}=3.259\right)$ were statistically significant on laterite soil-cement-SHF mixtures; however, cement has a more pronounced effect. Detailed results are shown in Table 3.

On the other hand, two-way analysis of variance (ANOVA) on the results of soaked CBR test shows that the effect of both cement $\left(\mathrm{F}_{\mathrm{CAL}}=0.457<\mathrm{F}_{\mathrm{CRIT}}=3.490\right)$ and $\mathrm{SHF}\left(\mathrm{F}_{\mathrm{CAL}}=1.713<\mathrm{F}_{\mathrm{CRIT}}=3.259\right)$ was statistically insignificant on laterite soil-cement-SHF mixtures. Detailed results are shown in Table 3. 


\section{Regression Analysis}

Regression analysis, a statistical procedure for establishing the relationship between two or more variables, predicting basically the effect of one or more variables (independent) on another variable (dependent), and determining the causal inference (Campbell and Campbell, 2008), was employed. Past researchers (Yohanna et al., 2015; Osinubi et al., 2016; Oluremi et al., 2018; Yohanna et al., 2018) used regression models for geotechnical engineering applications.

\section{Unconfined Compressive strength}

Regression model (Equation 4) was developed from laboratory based results of measured compaction parameters and admixtures content. This was used for predicting unconfined compressive strength from the measured laboratory unconfined compressive strength values. Equation 4 and the results of regression analysis for unconfined compressive strength (UCS) cured for 14 days showed the influence of maximum dry density (MDD), optimum moisture content $(\mathrm{OMC})$, Cement(C), and synthetic hair fiber (SHF) contents on the UCS of the stabilized soil. From the regression model, generally, the correlation coefficient value $\left(R^{2}\right)$ of $82.9 \%$ shows that a strong relationship exists between UCS and the independent parameters.

$U C S=3303-1640 M D D-48.5 O M C+582 C+7.5 H F$

$R^{2}=82.9$

Cement and SHF content with positive coefficients have the highest significant effect on the unconfined compressive strength. However, compaction characteristics, that is, MDD and OMC, with negative coefficients in the model have strength reduction effect on the UCS. Predicted results from the regression model indicated that a strong relationship exists between the measured unconfined compressive strength values obtained from the laboratory and the predicted values from the model based on second order polynomial relationship with approximate correlation coefficient $\mathrm{R}^{2}=0.87$ (see Figure 12).

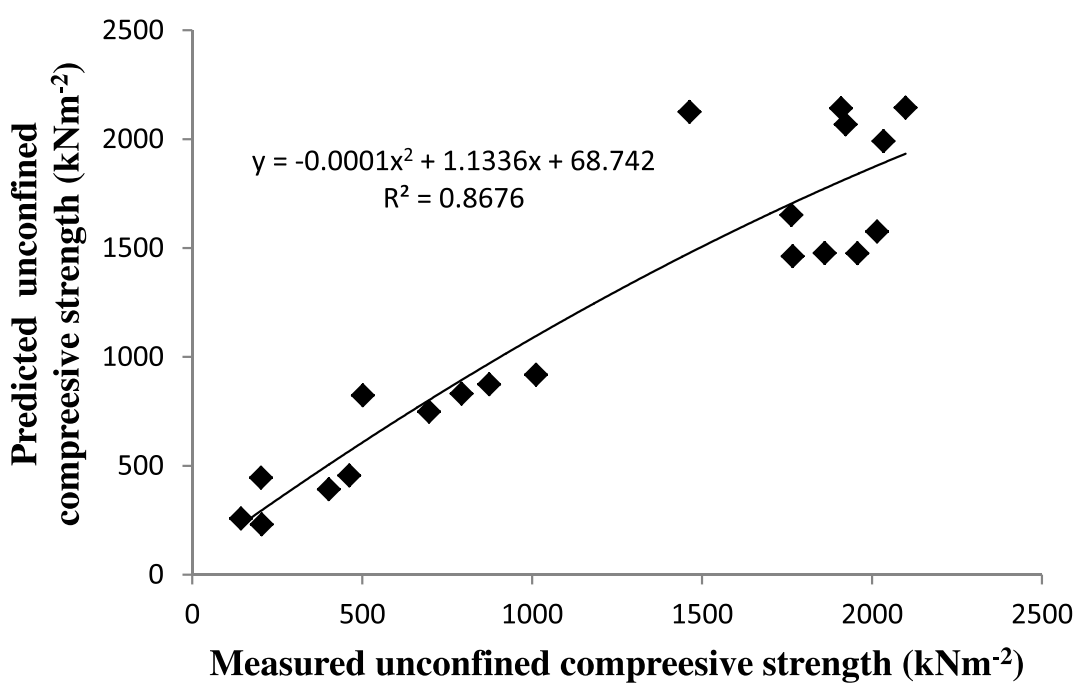

Figure 12. Comparison between the measured and the predicted unconfined compressive strength.

\section{California bearing ratio}

Similarly to UCS, the regression model for predicting CBR from compaction characteristics and admixtures content was developed from measured laboratory based CBR results. The regression equation is 
$C B R=58-28.3 M D D-0.34 O M C+9.15 C+0.948 H F$

$R^{2}=83.3$

Equation 5 and the results of regression analysis on California bearing ratio (CBR) showed the influence of maximum dry density (MDD), optimum moisture content (OMC), cement(C), and synthetic hair fiber (SHF) content on the values of CBR of the stabilized soil. Cement and the SHF content with positive coefficients have the most significant effect on the CBR, while reduction effect on the CBR will be initiated by compaction characteristics (maximum dry density and optimum moisture content) resulting from their negative coefficients in the model. Although the correlation coefficient $\left(R^{2}\right)$ of the model established a strong relationship between CBR and the independent parameters with $R^{2}$ value of $83.3 \%$ (See equation 5), there is no correlative relationship between the predicted results from the model and the measured values obtained in the laboratory using a second order polynomial relationship with correlation coefficient $\mathrm{R}^{2}=0.271$ (see figure 13). Hence, CBR values of the Cement-SHF modified laterite soil cannot be predicted from the developed model.

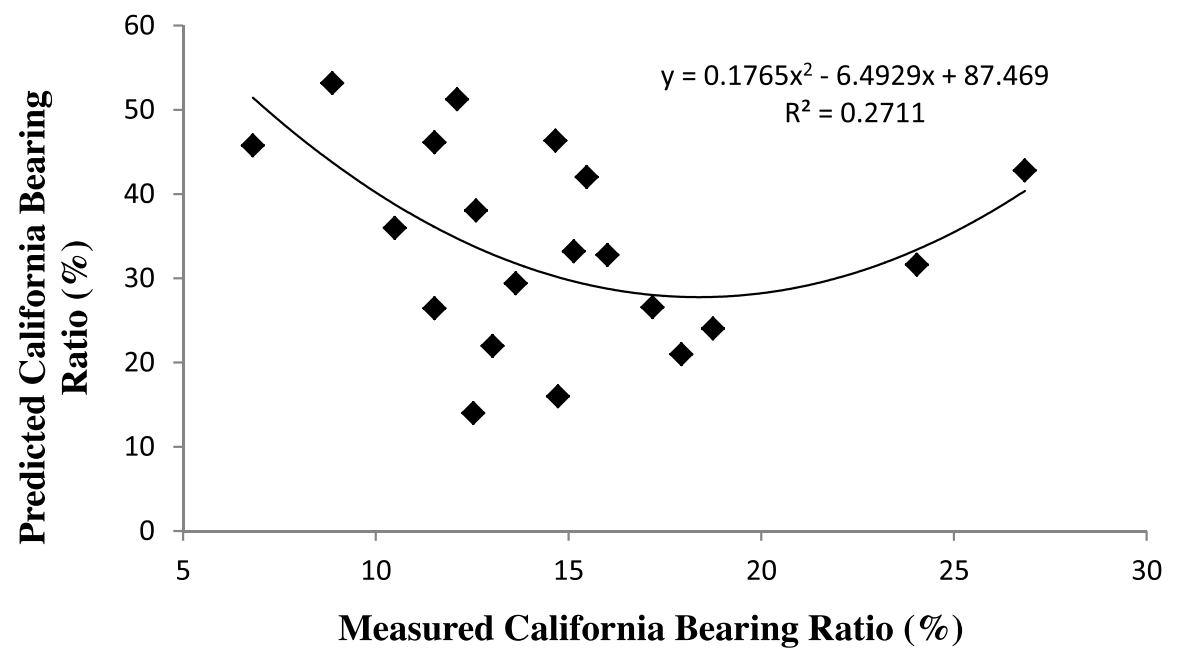

Figure 13. Comparison between the measured and the predicted unconfined compressive strength.

\section{CONCLUSION}

Based on the results of the laboratory geotechnical tests carried out on both the natural and cement-SHF stabilized laterite soil samples, the following conclusions were derived:

i. The natural soil was classified as A-5 (4) soil group according to AASHTO soil classification system and ML-CL based on Unified Soil Classification System (USCS).

ii. No precise trend was established for maximum dry density (MDD), but there was a decrease in optimum moisture content (OMC) of the samples.

iii. There was an increase in UCS and CBR values with an increase in both cement and SHF content.

iv. Statistical analysis showed some level of significance on the measured geotechnical properties of the laterite soil. Regression analysis of the results using Minitab R15 software showed that MDD, OMC, cement, and synthetic hair fibers significantly influence the soils UCS and CBR values.

v. Correlation coefficient value $\left(R^{2}\right)$ established that a strong relationship exists between UCS, CBR, and the compaction characteristics and admixtures content with $R^{2}$ values of 82.9 and $83.3 \%$, respectively. Therefore, 
it is important to ascertain good quality control of those variables in the model both in specification and control during field compaction to achieve durable road pavement strong enough to resist disturbing force of both traffic and unfavourable weather condition.

vi. An optimal blend of 3\% cement and 9\% SHF significantly improved the soil properties and is therefore recommended for stabilization to achieve improvement in the geotechnical properties of laterite soil as road construction material.

\section{FURTHER STUDIES}

Further research can be conducted on the efficiency of random placement of the fiber in soil as well as the use of different size of synthetic hair fiber in cement stabilized lateritic soil.

\section{REFERENCES}

AASHTO 1986. Standard Specification for Transportation, Material and Methods of Sampling and Testing. 14th Edition. Amsterdam Association of State Highway and transportation official Washington D.C.

Abebaw, Z. 2005. Basic Engineering properties of lateritic soils found in Nejo-mendi road construction area, Welega. Unpublished $\mathrm{PhD}$ Thesis submitted to the School of Graduate Studies of Addis Ababa University, Ethiopia.

Abhijith R.P. 2015. Effect of Natural Coir fibres on CBR Strength of Soil Subgrade, International Journal of Scientific and Research Publications, 5(4): ISSN 2250-3153.

Adedokun, S.I., Oluremi, J.R., Adekilekun, N.T. \& Adeola, O.V. 2018. Effect of Cement Kiln Dust on the Geotechnical Properties of Clay in Ede East Local Government Area. LAUTECH Journal of Civil and Environmental Studies (LAUJOCES), 1(1): 44-49. www.laujoces.org

Ahmad, S. 2014. Preparation of Eco-Friendly Natural Hair Fibre Reinforced Polymeric Composite (FRPC) Material by Using Of Polypropylene and Fly Ash: A Review", International Journal of Scientific \& Engineering Research, ISSN : 2229-5518, Volume 5, Issue 11, November-2014.

Akbulut, S., Arasan, S. \& Kalkan, E. 2007. Modification of clayey soils using scrap tire rubber and synthetic fibres, Applied Clay Science, 38: 23-32.

ASTM 1992. Annual Book of Standards. Vol. 04.08, American Society for Testing and Materials. Philadelphia.

Bagheri, Y., Ahmad, F. \& Ismail, M.A.M. 2014. Strength and mechanical behaviour of soil-cement-lime-rice husk ash (soil-CLR) mixture. Materials and Structures, 47(1-2): 55-66.

Basha, E.A., Hashim, R., Mahmud, H.B. \& Muntohar, A.S. 2005. Stabilization of residual soil with rice husk ash and cement. Construction and Building Materials, 19(6): 448-453.

Blight, G.E. 1997. Mechanics of Residual soils. A.A. Balkema (Ed), Netherlands.

BS 1377 1990. Method of Testing Soils for Civil Engineering Purpose. British Standard Institute, BSI, London.

BS 1924 1990. Method of Test for Stabilized Soils. British Standard Institute BSI, London.

Campbell, S. \& Campbell, D. 2008. Introduction to Regression and Data Analysis Statlab Workshop Series. 1-15, http://www. yale.edu/statlab.

Centre for Earthwork Engineering Research, CEER 2013. Cement Stabilization of Subbase and Subgrade. Boone County Expo Test Sections TECHNICAL BRIEF of Institute of Transportation Iowa Department of Transportation, http://www.ceer. iastate.edu.

Deepjyoti, D., Dhrubajyoti, K., Raja, S. \& Bikramjit, D. 2016. Shear Strength Enhancement of Sandy Soil Using Hair Fibre. International Journal of Innovative Research in Science, Engineering and Technology, 5(5): 8278-8283. DOI:10.15680/ IJIRSET.2016.0505212 8278.

Estabragh, A.R., Bordbar, A.T. \& Javadi, A.A. (2011). Mechanical Behaviour of a Clay Soil Reinforced with Nylon Fibers. Geotechnical Geological Engineering. 
Head, K.H. 1992. Manual of Soil Laboratory Testing Vol. 2 Pentech Press, London, Plymouth.

Inod, P., Bhaskar, A. \& Lekshmi, C.S. 2007. Triaxial Compression of Clay Reinforced with Sand-Coir Fiber Core. Geotechnical Testing Journal, 30(4): 1-4, http://dx.doi.org/10.1520/GTJ12639. ISSN 0149-6115.

Kalpana, M. \& Solanki C.H. 2009. Behaviour of Fiber Reinforced Soil. Australina Geomatics, 44(4): 65-74.

Kumar, S. \& K.Dutta, R. 2014. Unconfined compressive strength of bentonite-lime-phosphogypsum mixture reinforced with sisal fibers. Jordan Journal of Civil Engineering, vol. 8, no. 3, pp. 239-250.

Lo, S.R. \& Wardani, S.P.R. 2002. Strength and dilatancy of a stabilized by a cement and fly ash mixture. Canadian Geotechnical Journal, 39(1), 77-89.

Manjunath K.R, Venugopal G and Rudresh A.N. 2013. Effect of Random Inclusion Of Sisal Fibre On Strength Behavior Of Black Cotton Soil. International Journal of Engineering Research \& Technology Vol. 2 Issue 7, ISSN: $2278-018$.

Ochepo, J. 2014. Stabilization of laterite soil using reclaimed asphalt pavement and sugarcane bagasse ash for pavement construction. Journal of Engineering Research, 2(4):1-13.

Ola, S.A. 1974. Need for estimated cement requirement for stabilizing lateritic soil. Journal of Transportation Div., ASCE, 17(8): 379-388.

Oluremi, J.R., Osuolale, O.M. Adeoye, T.T. \& Akingbade, A.A. 2016b. Strength Development in Lateritic Soil Stabilised with Coconut Shell Ash for Highway Pavement Construction, Innovative Systems Design and Engineering, 7(11): 49-56.

Oluremi, J.R., Adedokun, S.I. \& Osuolale, O.M. 2012. Stabilization of Poor Lateritic Soils with Coconut Husk Ash. International Journal of Engineering Research \& Technology (IJERT) 1(8): 1-9. www.ijert.org ISSN: $2278-0181$.

Oluremi, J.R., Adedokun, S.I. Olaoye, R.A. \& Ajamu, S.O. 2012. Assessment of Cassava Wastewater on the Geotechnical Properties of Lateritic Soil. Pacific Journal of Science and Technology. 13(1): 631-639(Online). http://www.akamaiuniversity. us/PJST.htm.

Oluremi, J.R., Fagbenro, K.O., Osuolale, O.M. \& Olawale, A.M. 2018. Stabilization of Lateritic Soil Admixed with Maize Husk Ash. LAUTECH Journal of Civil and Environmental Studies (LAUJOCES), 1(1): 21-30. www.laujoces.org

Oluremi, J.R., Ijimdiya, S.T., Eberemu, A.O., \& Osinubi, K.J. 2018. Reliability Evaluation of Hydraulic Conductivity Characteristics of Waste Wood Ash Treated Lateritic Soil, Geological and Geotechnical Engineering, 37(2): 533-547. https://doi.org/10.1007/s10706-018-0625-5

Oluremi, J.R., Siddique, R. \& Adeboje, E.P. 2016b. Stabilization Potential of Cement Kiln Dust Treated Lateritic Soil. International Journal of Engineering Research in Africa, 23: 52-63. doi:10.4028/www.scientific.net/JERA.23.52.

Oriola, F. \& Moses, G. 2010. Groundnut Shell Ash Stabilization of Black Cotton Soil Electronic Journal of Geotechnical Engineering, 15: 415-428.

Osinubi, K.J, Eberemu, A.O., Yohanna, P. \& Etim, R.K. 2016. Reliability Estimate of Compaction Characteristics of Iron Ore Tailings Treated Tropical Black Clay as Road Pavement Sub-Base Material. ASCE Geotechnical Special Publication, 271: $855-864$

Osinubi, K.J, Yohanna, P. \& Eberemu, A.O. 2015. Cement Modification of Tropical Black Clay Using Iron Ore Tailing as Admixture. Journal of Transportation Geotechnics. 5: 35-49. http://dx.doi.org/10.1016/j.trgeo.2015.10.001.

PCA. 1995. Soil-Cement Construction Handbook, Portland Cement Association (PCA), Skokie, Illinois.

Ramesh, H.N., Manoj-Krishna, K.V. \& Mamatha, H.V. 2010. Compaction and strength behavior of lime-coir fiber treated Black Cotton soil. Journal of Geomechanics and Engineering, 2(1): 19-28. DOI : 10.12989/gae.2010.2.1.019.

Rohin, K. 2014. An Innovative Technique of Improving the C.B.R Value of Soil Using Hair fibre, Global Journal of Engineering Science and Researches. 1(4): 1-6.

Roy, A. 2014. Soil stabilization using rice husk ash and cement. International Journal of Civil Engineering Research, 5(1): 49-54.

Sanjay, C. \& Bhawana, P. 2012. Mechanical Behaviour of Polypropylene And Human Hair Fibres And Polypropylene Reinforced Polymeric Composites, International Journal of Mechanical and Industrial Engineering, 2(1): 118-121.

Tomas, U.G. 2014. Effects of Human Hair Additives in Compressive Strength of Asphalt Cement Mixture. International Journal 
of Advanced Science and Technology, 67: 11-22 http://dx.doi.org/10.14257/ijast.2014.67.02.

Treasa, M. \& Sudheesh, T. 2013. Influence of Randomly Distributed Coir Fibers on Shear Strength of Clay. Geotechnical and Geological Engineering, 31(2): 425-433.

Uddin, K., Balasubramaniam, A.S. \& Bergardo, D.T. 1997. Engineering behaviours of cement-treated Bangkok soft clay. Geotechnical Engineering Journal, (28)1, 89- 119.

Wajid A.B., Karan G., Hamidullah N. \& Showkat, M.B. 2014. Soil Sub- grade Improvement Using Human Hair Fiber. International Journal of Scientific and Engineering Research, 5(12): 977-981.

Wajid A.B., Mir, B.A. \& Jha, J.N. 2016. Strength Behavior of Clayey Soil Reinforced with Human Hair as a Natural Fibre. Geotechnical and Geological Engineering, 34(1): 411-417.

Yohanna, P., Nwaiwu, C.M.C. \& Oluremi, J.R. 2015. Effect of Sample Re-use on the Compaction Characteristics of Concretionary Lateritic Soil as Subgrade Material. International Journal of Scientific and Engineering Research. 6(5): 513-523.

Yohanna, P., Oluremi, J.R., Eberemu, A.O., and Osinubi, K.J. \& Sani, J E. 2018. Reliability Assessment of Bearing Capacity of Cement-Iron Ore Tailing Blend Black Cotton Soil for Strip Foundations, Geological and Geotechnical Engineering, 37(2): 915 - 929. https://doi.org/10.1007/s10706-018-0660-2

Submitted: 10/07/2017

Revised: $\quad 08 / 02 / 2018$

Accepted: 11/03/2018 


\section{تقييم تربة اللاتريت المضغوطة المخلوطة بالأسمنت و ألياف الشعر كمواد لبناء الطرق

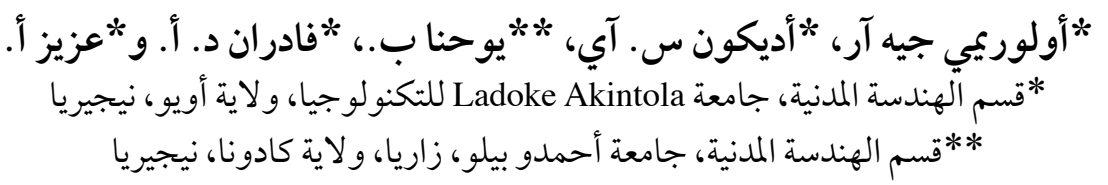

\section{الخلاصة}

تربة اللاتريت الطبيعية المُصنفة على أنها (4) A-5 بناءً على نظام تصنيف التربة التابع للجمعية الأمريكية لمسؤولي الطرق

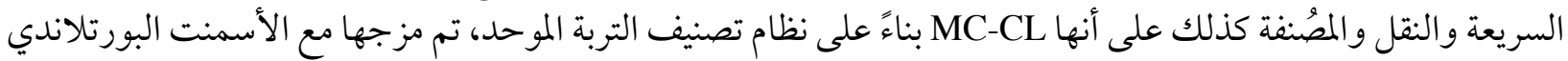

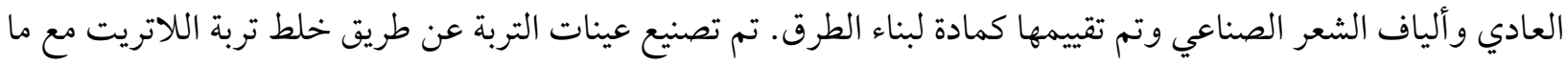

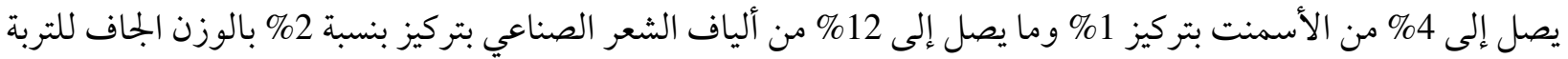

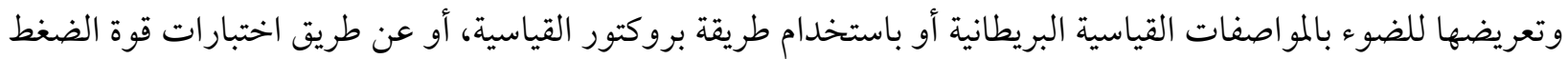

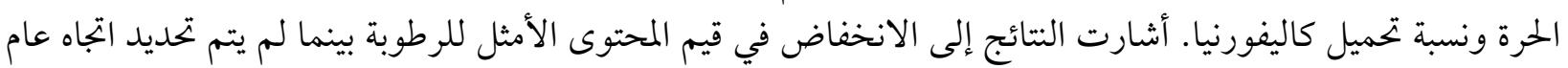

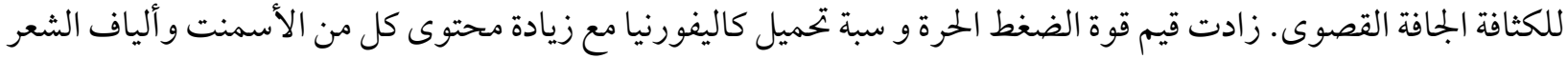

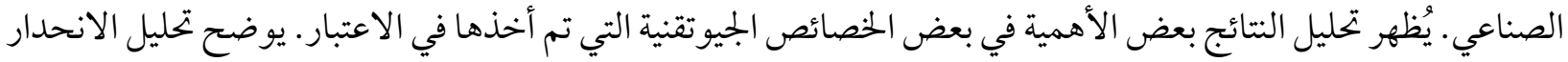

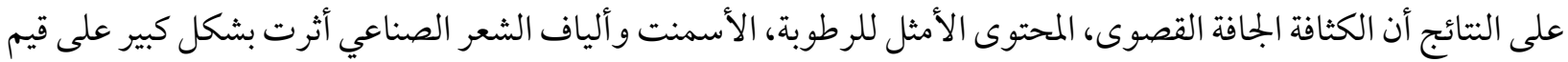

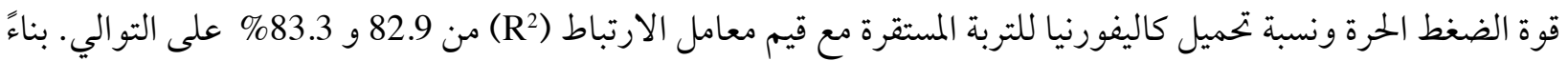

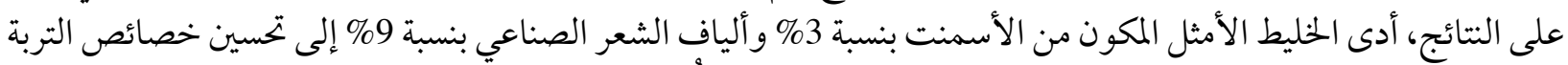

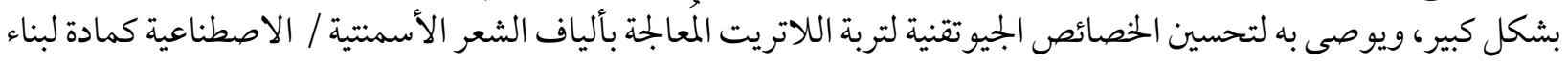
الطرق. 